\title{
Quinoa (Chenopodium quinoa) Grains Processing and its Value Added Products
}

\author{
S. M. Pritham ${ }^{1}$, M. L. Revanna ${ }^{1}$, Usha Ravindra ${ }^{1}$, B. Kalpana ${ }^{2}$, \\ Niranjana Murthy ${ }^{3}$ and Madhusudan ${ }^{4}$ \\ ${ }^{1}$ Department of Food Science and Nutrition, ${ }^{2}$ Post-Harvest Technology Unit, \\ ${ }^{3}$ AICRN (Under utilized crops), \\ ${ }^{4}$ Deparment of Genetics and Plant Breeding, UAS, GKVK, Bangalore, Karnataka, India \\ *Corresponding author
}

\section{A B S T R A C T}

Quinoa is a pseudocereal, a native to Andean regions. Recently it is gaining importance due to its nutritional composition. Raw and dehulled quinoa

Keywords

Germination, roasting, quinoa grain flour, sensory evaluation, chikki

Article Info

Accepted:

22 March 2021

Available Online:

10 April 2021 grains were procured from Hyderabad. Raw quinoa grains were pre-soaked (6, 8 and 10 hours) and germinated for 12 and 24 hours. Three different temperature $\left(80^{\circ}, 100^{\circ}\right.$ and $\left.120^{\circ} \mathrm{C}\right)$ was allowed in the roasting process. Further value added products were developed by incorporating germinated quinoa grain flour at different variations $(25,50,75$ and 100 per cent). Whereas, chikki was developed by roasted quinoa grains at different incorporation per cent level (50, 75 and 100 per cent). Processing methods showed that 8 hours of pre soaking and 24 hours of germination had acceptable sprout length and germination percentage. In roasting process $120^{\circ} \mathrm{C}$ for 7 minutes had acceptable sensory scores. Sensory evaluation of value added product showed that 100 per cent incorporated in processed quinoa beverage found to be highly acceptable and 75 per cent of roasted quinoa showed 8.65 mean overall acceptability scores. Thus it was concluded that processing methods influenced that sensory scores and quinoa can be acceptable upto 100 per cent in the value added products.

\section{Introduction}

Recently there are large cereals varieties can be used for human nutrition and starchy food that consumed similarly as cereals, so called pseudocereals. Pseudocereals are not cereals but they produce cereal like grain and they are dicotyledonous unlike true cereals which are monocots. They are underutilized crops and during the last decades they were recognized as important for food security and human health components (Sinkovic, 2016). Quinoa 
(Chenopodium quinoa sub $s p$. quinoa) is a one such best known pseudocereal and which is recently gaining importance. (Mir et al., 2018)

Quinoa is an indigenous to the Andean region of South America which belongs to the Chenopodiaceae family, genus Chenopodium. Its botanical name is Chenopodium quinoa Willd. It produces flat, oval-shaped seeds that are usually pale yellow but can range in color from pink to black. White color grains are the most popular one.

Quinoa is used globally because of the nutritional composition and its protein mainly rich in lysine with good amount of essential amino acids. It is an amylaceous grain that has a high carbohydrate content, mainly consisting of starch and a small percentage of sugars. Protein content in the dry matter of quinoa seeds varies between 13.8 and 16.5 per cent; however, it is reported as 15 per cent on an average. The total protein content of quinoa is higher than that of rice, barley, corn, rye, and sorghum, and is close to wheat (Anonymous, 2015).

Quinoa is used as same as our rice, which can be cooked and served. It can be popped, extruded and used as snacks. It is ground into flour and used for making chapathis, breadmaking, pasta, biscuits, and other processed foods (Diaz et al., 2013). CFTRI has unveiled quinoa as super foods with wide variety of ready to eat foods can made from these high nutrients grains. Abugoch et al., (2009) studied that quinoa flour can be stored at ambient temperature (between 20 and $30^{\circ} \mathrm{C}$ ) which were packed in double kraft paper bags for 2 months. Pasta can be developed with proportion 60:20:20:6:12 of buckwheat, amaranth, quinoa, egg white powder and emulsifier. Also, the pasta exhibited acceptable firmness and cooking quality compared to wheat pasta (Schoenlechner et al., (2010). Bianchi et al., (2015) developed symbiotic fermented beverage with aqueous extracts of quinoa and soy. Results showed that beverage with 70 per cent soy and 30 per cent quinoa extracts obtained best sensory acceptance. Moreover, India has got more population with less access to protein rich diet, since we use rice and wheat as staple food. Quinoa is proteinaceous with good essential amino acids and helps to handle balanced diet.

\section{Materials and Methods}

Andhra Pradesh local variety white bold quinoa (Raw and dehulled grains) were procured form Kilaru Naturals Private Limited, Hyderabad. Grains were cleaned for extraneous materials and stored in deep freezer and used for further processing.

\section{Standardization of processing methods}

Domestic processing methods were carried $v i z$, germination and roasting methods.

\section{Germination}

Thousand counted and weighed grains were soaked separately for $6 \mathrm{hrs}, 8 \mathrm{hrs}$ and $10 \mathrm{hrs}$ tied in muslin cloth and subjected for 12 and 24 hours for germination. Germinated grains were dried at $40^{\circ} \mathrm{C}$ in hot air oven for 4 hours. Germinating characteristics of grains viz., germination percentage and sprout length of quinoa grains were measured by Pinzino (1999) method with slight modifications. Sprout length was observed and noted for different soaking and germination time

\section{Germination percentage \\ Number of grains that germinated

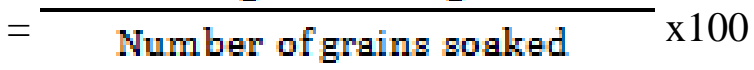

\section{Roasting}

Processed (dehulled) grains were washed under running water thoroughly. It was soaked 
for $2 \mathrm{hrs}$, dried at $60^{\circ} \mathrm{C}$ for $4 \mathrm{hrs}$ and roasted on open pan at three different temperatures using digital multi-thermometer with external sensor probe $\left(80^{\circ}, 100^{\circ}\right.$ and $\left.120^{\circ} \mathrm{C}\right)$. Roasted grains were subjected for the sensory evaluation. Best accepted grains were milled for product development.

\section{Product development}

Value added product was developed based on the processing method (germination and roasted quinoa grains).

\section{Preparation of processed quinoa beverage mix $(\mathbf{Q B M})$}

Quinoa, green gram was soaked for eight hours and germinated for 24 hours. Germinated ingredients were dried for 4 hours at $60^{\circ} \mathrm{C}$ in hot air oven and roasted on frying pan until flavour developed (4-6 mins). Then it is powdered separately and used for the preparation of processed quinoa beverage mix (Fig.1). The incorporation of germinated quinoa varied from 25 to 100 per cent. Mix was reconstituted with $300 \mathrm{ml}$ of milk and compared with control which was prepared with germinated wheat.

\section{Preparation of Chikki}

Quinoa chikki was prepared using roasted quinoa and compared with peanut chikki. (Fig. 2).

\section{Sensory evaluation}

All the products were evaluated by panel of semi-trained panel member $(n=21)$. The products were evaluated for the appearance, color, texture or mouth feel, taste, flavor and overall acceptability on nine-point hedonic scale. Where Scoring system: 9-like extremely, 8-Like very much, 7-Like Moderately, 6-Like slightly, 5-Neither like nor dislike, 4-Dislike slightly, 3-Dislike moderately, 2-Dislike very much, 1- Dislike extremely.

One-way analysis of variance (F-test) in SPSS sensory mean scores of panel members in order to find the significant difference between the different characteristics of products, under the study.

\section{Results and Discussion}

\section{Germination}

Influence of different soaking time of quinoa seeds on germination percentage was depicted in Fig. 3. The study results revealed that the germination percentage is directly proportional to the soaking time. Germination percentage ranged from 10 per cent (6hrs of soaking with $12 \mathrm{hrs}$ of germination) to 70 per cent in $10 \mathrm{hrs}$ of soaking with $24 \mathrm{hrs}$ of germination. This may be due to the hydrolysis of complex sugars to simple sugars which are utilized during germination. Results were in line with Nadeem et al.,(2017) studied optimum soaking time for the better germination in maize and reported that cell wall of seeds were softened due to the production of auxins which enhances growth of new tissues. In the present study sprout length varied from $0.88 \mathrm{~mm}$ and $1.96 \mathrm{~mm}$ in 12 hrs and 24 hrs germinated seeds respectively. Whereas ideal sprout length i.e., $2 \mathrm{~mm}$ of was observed in the seeds soaked for $8 \mathrm{hrs}$ which are germinated at 24hrs. American Association of Cereal chemist and USDA (Benincasa et al., 2019) reported that the germinated seeds should contain bran, germ, endosperm and sprout growth should not exceed the kernel length. Furthermore, Table 1 depicted the observations during germination process and it was found to be eight hours of soaking and 24 hours of germination was suitable. Hence, it was standardized and used for the further analysis. 


\section{Roasting}

Dehulled quinoa grains were roasted at different temperature to standardize the roasting temperature. Fig. 4 depicts that there is a significant difference between the roasting temperatures $\left(80^{\circ}, 100^{\circ} \mathrm{C}\right.$ and $\left.120^{\circ} \mathrm{C}\right)$. As the temperature increased sensory parameters from neither like nor dislike (5 score) to like extremely $(9$ score $)$. All the sensory parameters were highest in the grains which are roasted for $120^{\circ} \mathrm{C}$. Semi trained panel members liked very much (8 score) for appearance, color, mouth feel and overall acceptability whereas, flavor and taste scored 9 (Like extremely). The growth of characteristic color and flavor components in the grains was due to the process of maillard reaction (occurs when amino acids react with sugar reduction) and caramalization (sugar reaction) for taste. It depends on the roasting temperature and time. Similarly, Alba et al., (2019) used dry roasting for quinoa to enhance sensory characteristics as an alternative. It was also reported that in roasting, the maillard reaction depends on temperature, time and humidity. As the dry roast $\left(120^{\circ} \mathrm{C}\right)$ helps to evaporate water along with volatile off flavor compounds and produces more flavor compounds. Research by Carciochi, et al., 2016 showed that $130^{\circ} \mathrm{C}$ resulted in brown polymers formation. Therefore, $120^{\circ} \mathrm{C}$ with 7 minutes of low-flame roasting was standardized, milled and stored for further analysis.

\section{Development of value added products}

Processed quinoa beverage was prepared by the incorporating the germinated flour with germinated wheat flour at different variations (25, 50, 75 and 100 per cent). The mean sensory scores for the processed quinoa beverage at various levels of Quinoa incorporation are depicted in the Table 2 and Fig. 5. Mean scores of sensory parameters such as appearance and color were non significantly different with respect to different levels of incorporation. As the incorporation of quinoa increased appearance score was also decreased (8.38 for control and 8.19 for 100 per cent quinoa beverage). Where mouth feel, flavor, taste and overall acceptability were improved with higher per cent of quinoa incorporation. It may be due to the germination which increased the sugars levels and combination of powdered sugar and cocoa reduced the bitter taste of quinoa.

Table.1 Observation of quinoa seeds for the standardization of germination processing methods

\begin{tabular}{|c|l|l|l|}
\hline $\begin{array}{c}\text { Observation } \\
\text { Germination } \\
\text { time }\end{array}$ & \multicolumn{1}{|c|}{ 6hrs } & \multicolumn{1}{|c|}{ Shrs } & \multicolumn{1}{|c|}{$\mathbf{1 0 h r s}$} \\
\hline $\mathbf{1 2 h r s}$ & $\begin{array}{l}\text { Few seeds were } \\
\text { germinated } \\
\text { Sprout length were } \\
\text { within the desirable } \\
(0.88 \mathrm{~mm})\end{array}$ & $\begin{array}{l}\text { Sprout length were } \\
\text { within the } \\
\text { desirable }(1.23 \\
\mathrm{mm})\end{array}$ & $\begin{array}{l}\text { Sprout length were } \\
\text { with the desirable }(2 \\
\text { mm) but Seeds } \\
\text { developed off color }\end{array}$ \\
\hline $\mathbf{2 4 h r s}$ & $\begin{array}{l}\text { Sprout length were } \\
\text { within the desirable } \\
(1.23 \mathrm{~mm})\end{array}$ & $\begin{array}{l}\text { Sprout length were } \\
\text { within the } \\
\text { desirable }(2 \mathrm{~mm}) \\
\text { No signs of off colour }\end{array}$ & $\begin{array}{l}\text { Sprout length } \\
\text { exceeded the } \\
\text { desirable length and } \\
\text { colour }\end{array}$ \\
\hline
\end{tabular}


Table.2 Mean scores for processed quinoa beverage

\begin{tabular}{|c|c|c|c|c|c|c|}
\hline $\begin{array}{c}\text { Incorporation } \\
\text { Per cent levels }\end{array}$ & Appearance & Mouth feel & Color & Flavor & $\begin{array}{c}\text { Taste } \\
\text { Occeptability }\end{array}$ \\
\hline Control & $8.38 \pm 0.49$ & $7.64 \pm 0.82$ & $8.23 \pm 0.53$ & $7.54 \pm 0.68$ & $7.59 \pm 0.71$ & $7.88 \pm 0.37$ \\
\hline ABA & $8.26 \pm 0.43$ & $8.11 \pm 0.44$ & $8.11 \pm 0.63$ & $7.69 \pm 0.74$ & $7.76 \pm 0.75$ & $8.00 \pm 0.33$ \\
\hline ABB & $8.04 \pm 0.58$ & $8.14 \pm 0.65$ & $7.95 \pm 0.86$ & $8.19 \pm 0.65$ & $8.16 \pm 0.48$ & $8.10 \pm 0.28$ \\
\hline ABC & $8.19 \pm 0.67$ & $8.26 \pm 0.49$ & $8.14 \pm 0.79$ & $8.28 \pm 0.46$ & $8.18 \pm 0.53$ & $8.21 \pm 0.28$ \\
\hline ABD & $8.19 \pm 0.51$ & $8.33 \pm 0.57$ & $8.23 \pm 0.62$ & $8.35 \pm 0.42$ & $8.40 \pm 0.46$ & $8.30 \pm 0.32$ \\
\hline F-value & NS & $*$ & NS & $*$ & $*$ & $*$ \\
\hline SEm \pm & 0.169 & 0.189 & 0.216 & 0.188 & 0.185 & 0.104 \\
\hline CD@5\% & - & 0.567 & - & 0.556 & 0.555 & 0.312 \\
\hline
\end{tabular}

*Significant at 5 per cent level, ABA: 25 per cent incorporation of germinated quinoa flour (GQF) ABB: 50 per cent incorporation of germinated quinoa flour, ABC: 75 per cent incorporation of germinated quinoa flour ABD: 100 per cent incorporation of germinated quinoa flour

Table.3 Mean sensory score of Chikki

\begin{tabular}{|c|c|c|c|c|c|c|}
\hline Variation & Appearance & $\begin{array}{c}\text { Mouth } \\
\text { feel/texture }\end{array}$ & Color & Flavor & $\begin{array}{c}\text { Taste } \\
\text { Overall }\end{array}$ \\
\hline Control & $8.95 \pm 0.10$ & $8.00 \pm 0.77$ & $8.84 \pm 0.32$ & $8.81 \pm 0.40$ & $8.95 \pm 0.10$ & $8.71 \pm 0.21$ \\
\hline ABA & $8.72 \pm 0.46$ & $8.54 \pm 0.52$ & $8.59 \pm 0.66$ & $8.54 \pm 0.55$ & $8.36 \pm 0.50$ & $8.55 \pm 0.22$ \\
\hline ABB & $8.77 \pm 0.39$ & $8.50 \pm 0.48$ & $8.85 \pm 0.32$ & $8.77 \pm 0.39$ & $8.36 \pm 0.50$ & $8.65 \pm 0.22$ \\
\hline ABC & $8.98 \pm 0.39$ & $7.18 \pm 0.40$ & $9.00 \pm 0.00$ & $9.00 \pm 0.00$ & $8.27 \pm 0.46$ & $8.49 \pm 0.13$ \\
\hline F-value & NS & $*$ & NS & $*$ & $*$ & $*$ \\
\hline SEm \pm & - & 0.240 & - & 0.169 & 0.183 & 0.087 \\
\hline CD@5\% & - & 0.720 & - & 0.507 & 0.549 & 0.261 \\
\hline
\end{tabular}

*Significant at 5 per cent level, ABA: 50 per cent incorporation of roasted quinoa, ABB: 75 per cent incorporation of roasted quinoa, ABC: 100 per cent incorporation of roasted quinoa 
Fig.1 Flow chart for preparation of Processed quinoa Beverage mix

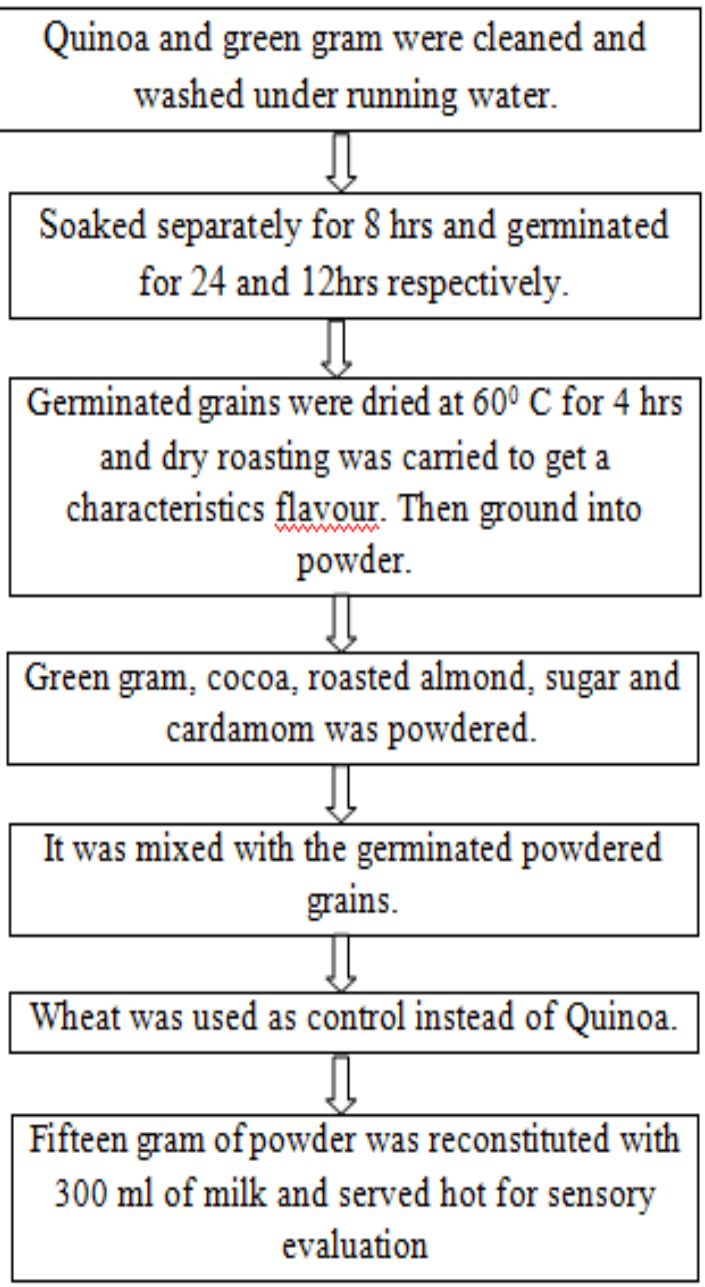

Germinated quinoa

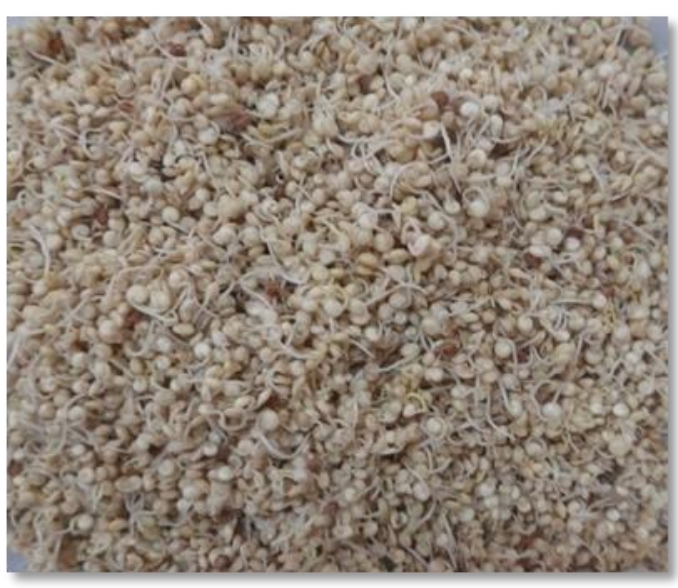

Processed quinoa beverage

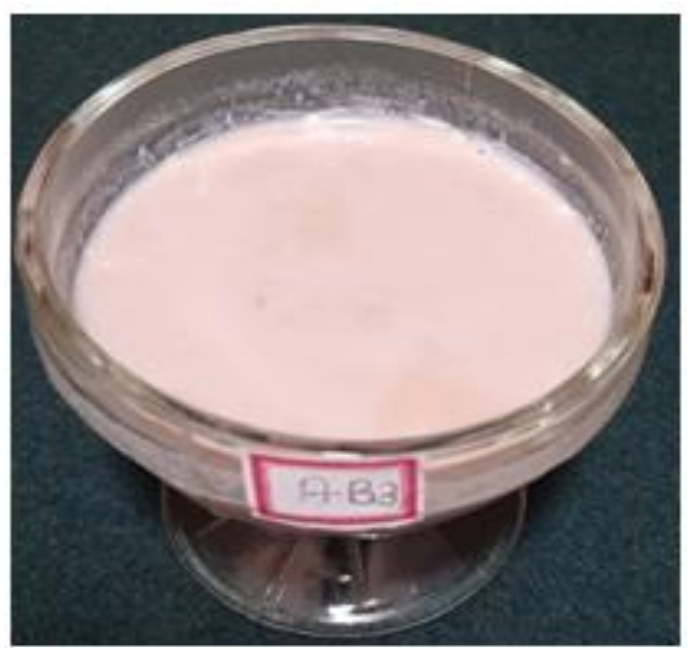


Fig.2 Preparation of roasted quinoa chikki

Quinoa soaked for $2 \mathrm{hrs}$, dried and roasted at $120^{\circ} \mathrm{C}$

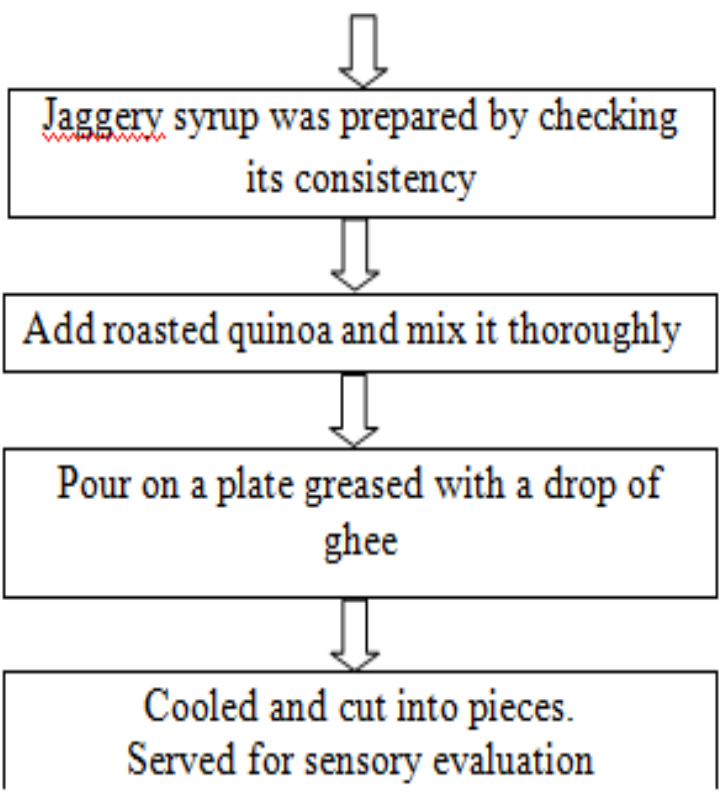

Roasted quinoa chikki

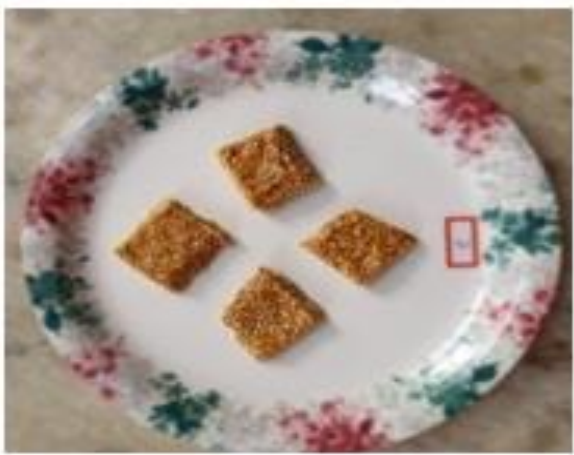

Fig.3 Germination percentage at different soaking time at room temperature.

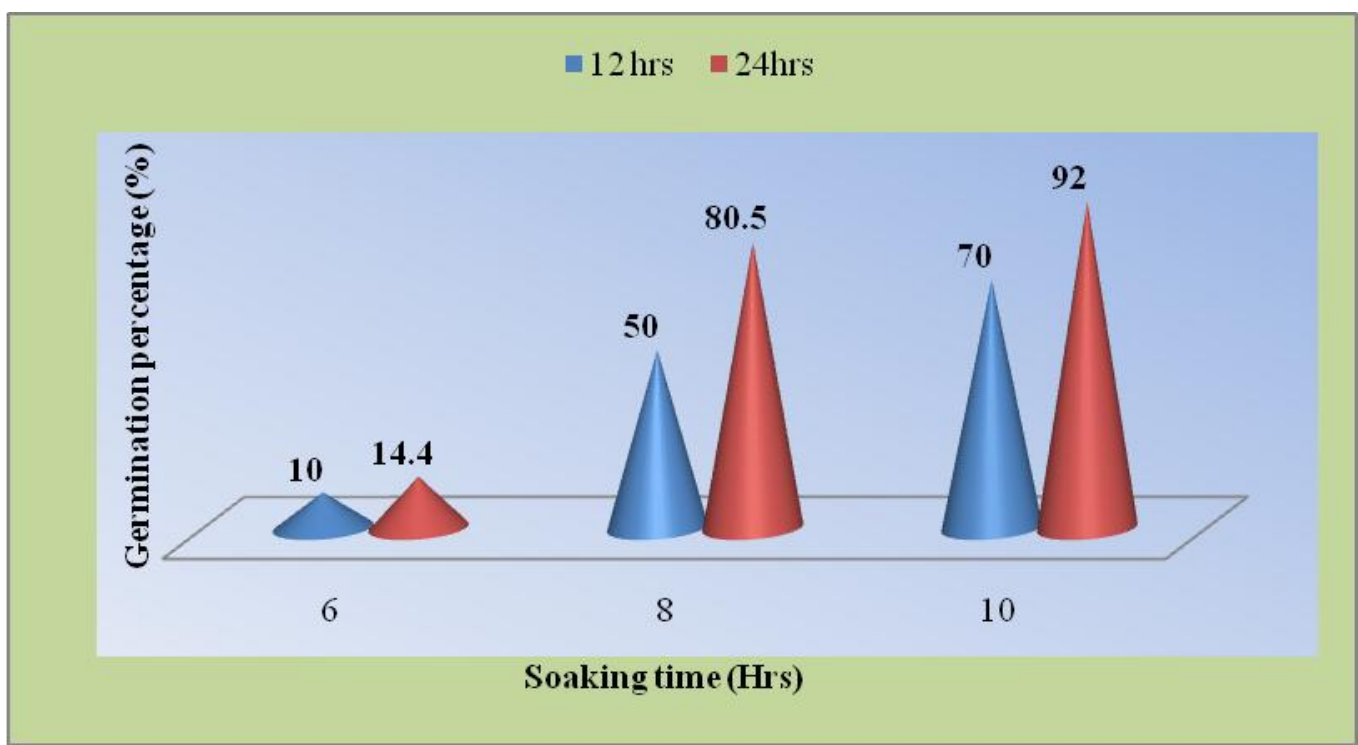


Fig.4 Sensory evaluation of roasted quinoa grains at different temperatures for standardization of roasting processing method. PBR1: Roasted at $80^{\circ} \mathrm{C}$; PBR2: Roasted at $100^{\circ} \mathrm{C}$; PBR3: Roasted at $120^{\circ} \mathrm{C}$.

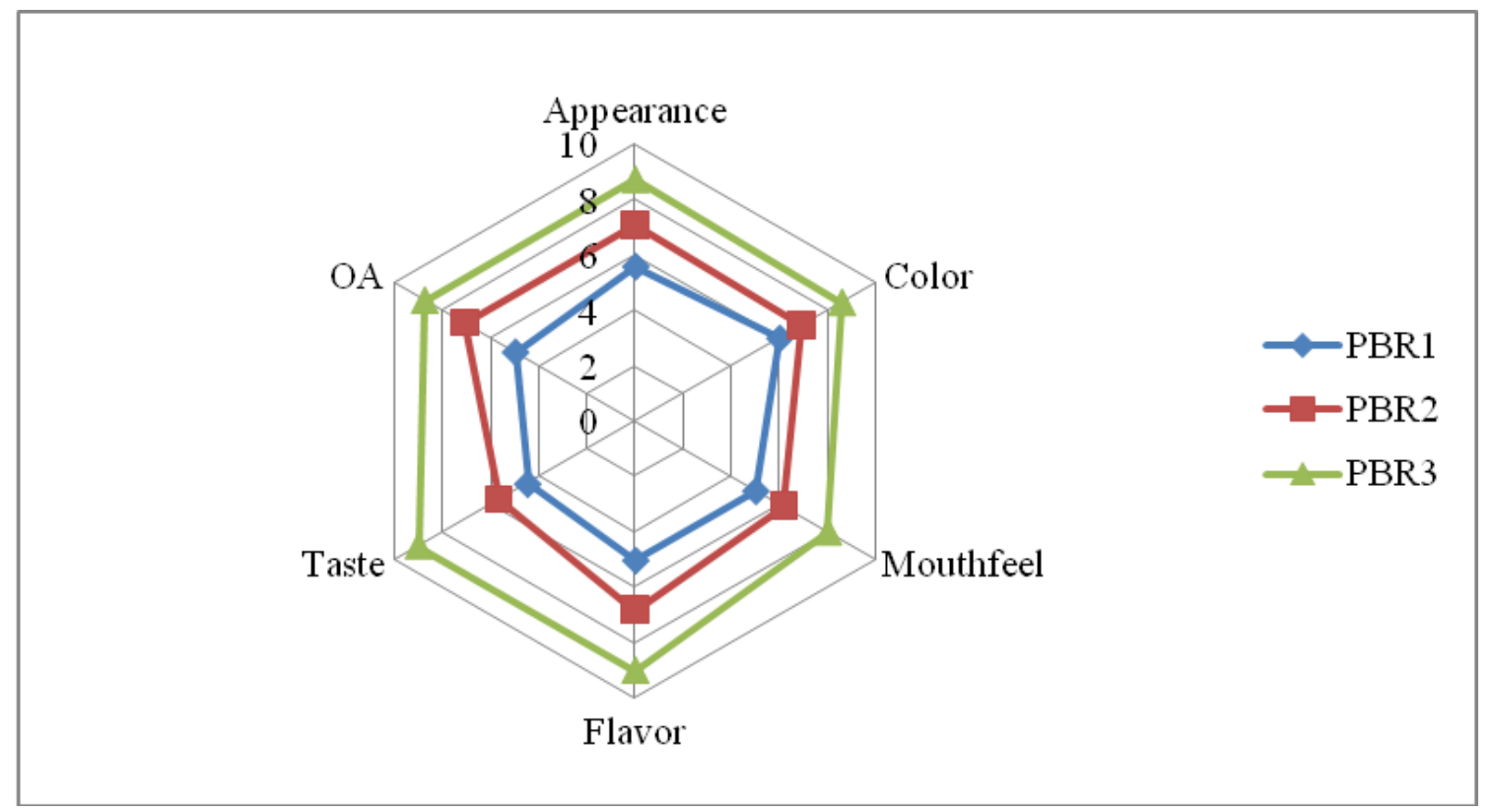

Fig.5 Mean sensory score of processed quinoa beverage

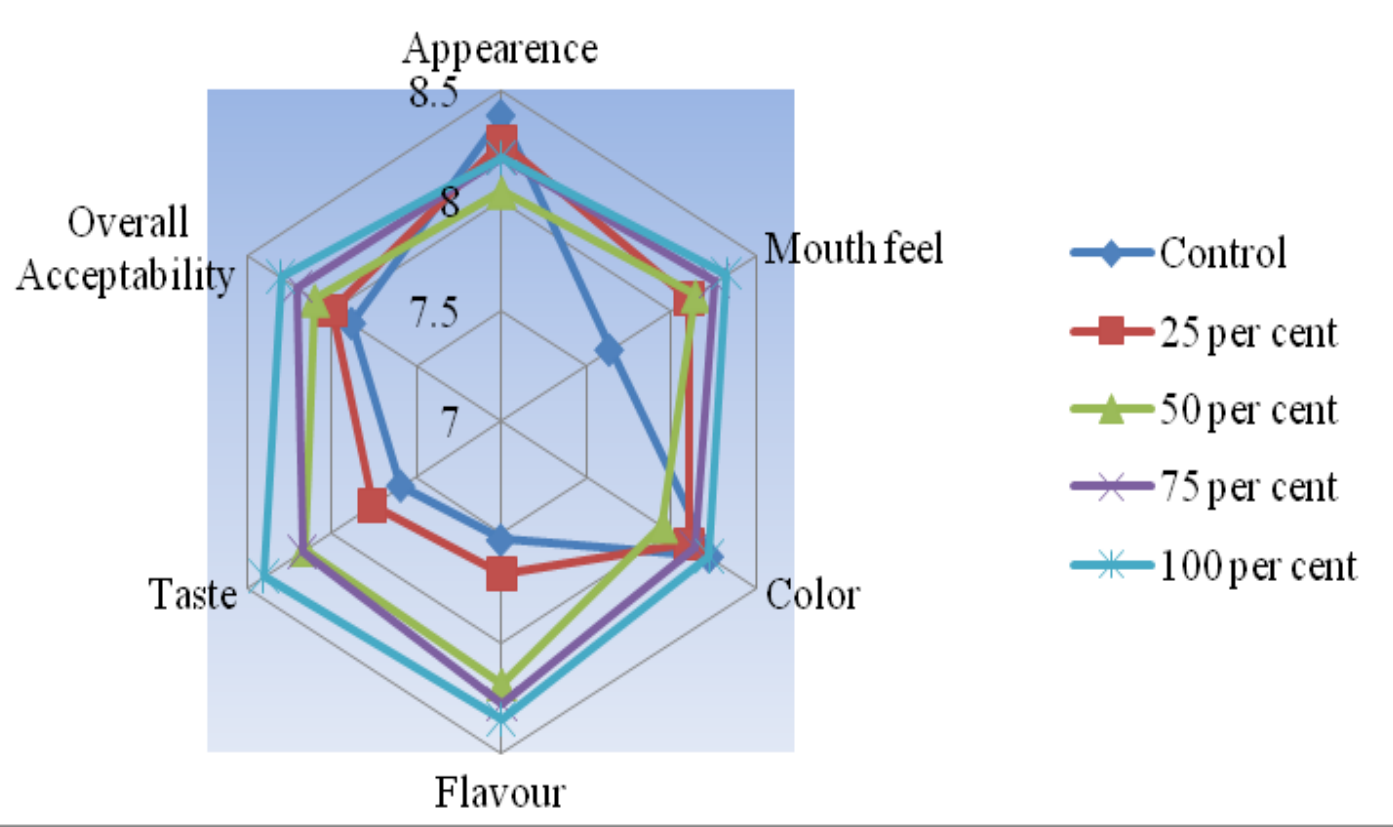


Fig.6 Mean sensory scores evaluation of Chikki

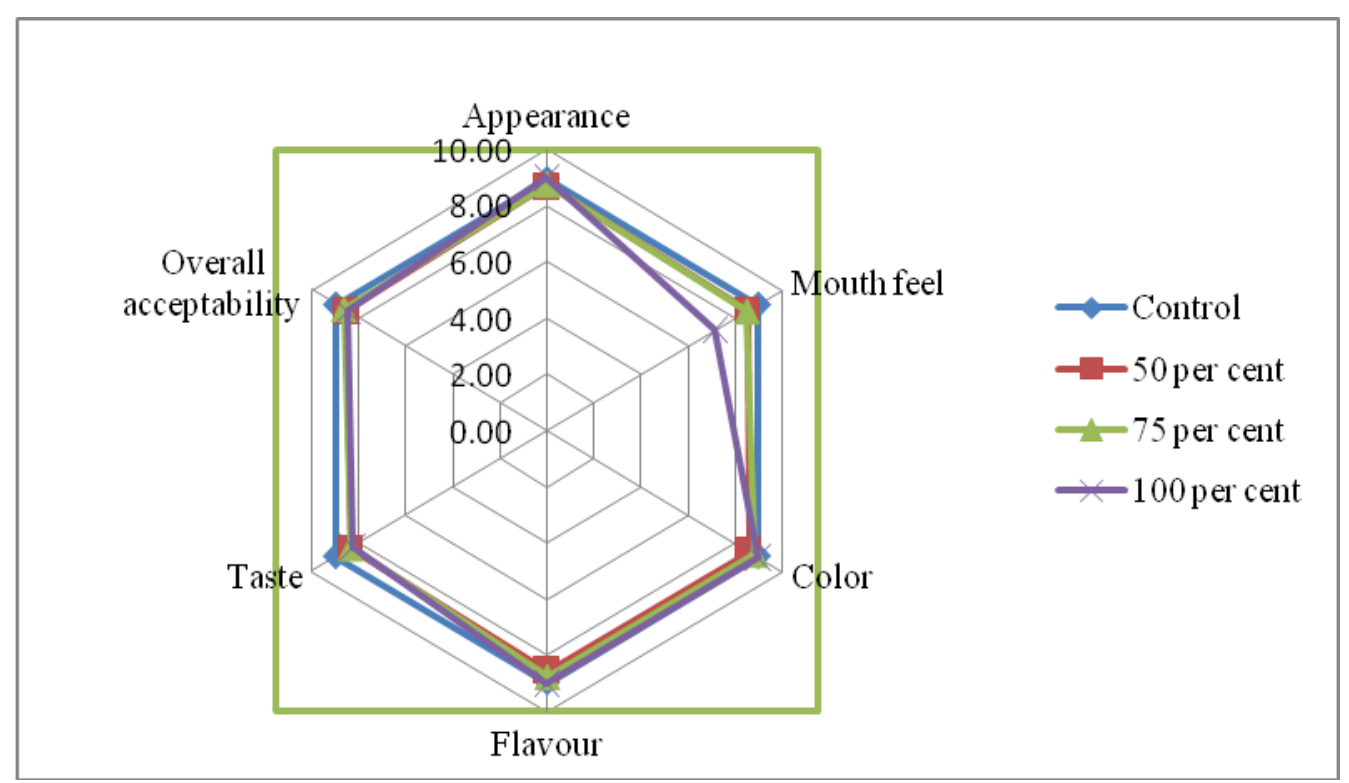

Thin consistency was observed with increase in quinoa per cent than the control may be due the absence of gluten. Sensory scores revealed that among variation, 100 per cent incorporated germinated quinoa was accepted and wheat based was least accepted. Kaur and Tanwar 2016, developed roasted quinoa milk beverage (RQB), soaked quinoa milk beverage(SQB), germinated milk beverage (GQB) and malted milk beverage (MQB) with $150 \mathrm{~g}$ of respective processed flour. Overall acceptability of quinoa beverages ranged from extremely dislike to moderately like, with the acceptability trend being: $\mathrm{RQB}<\mathrm{SQB}<\mathrm{MQB}<\mathrm{GQB}$. Germinated quinoa beverage was most liked among all quinoa beverages with an overall acceptability score matching significantly.

Gindy, 2018 reported mean sensory scores of the weaning food made from the flour blends of orange flesh sweet potato, germinated Pearl millet and precooked quinoa. Sample (PMQ) 10:30:60 had the highest value for taste, while sample 0:100:0 had the lowest value for taste.

The overall acceptability expresses how the consumer or the panelists generally accept the product so it was observed that PMQ weaning at 10:30:60 blend was highly accepted. Which concluded that as the incorporation percent of quinoa increased the acceptability scores. Miranda et al., 2018 also reported that the incorporation of dehulled quinoa flour in muffin development perceived bitter taste whereas, germinated influenced the taste and smell (sensory properties) with more acceptance.

\section{Quinoa Chikki}

Chikki is one of the best snacks. Roasted quinoa was used to develop Quinoa chikki. Traditional peanut chikki was considered as control and roasted peanuts were used along with roasted quinoa grains. Sensory scores of quinoa chikki was depicted in the Table 3 and Fig. 6. Appearance, color and flavor improved as the per cent of quinoa incorporation increased due to the characteristic odor of roasting and caramelization. While texture and taste were impaired with cent per cent incorporation, this was because of grainy texture of quinoa. Semi trained panelist 
reported that among variation 75 per cent of roasted quinoa and 25 per cent of roasted peanut scored 8.65 for overall acceptability.

Similar study was carried by Kavali et al., 2019 developed chikki, combination of ground nut and quinoa. Quinoa incorporation varied from 60 to 100 per cent. Variation with 60 per cent quinoa and 40 per cent groundnut scored highest for the overall acceptability with moderately liking.

The multigrain Nutri-chikkis prepared with of pumpkin seed, flax seed, ground nut, almond, foxtail millet, roasted Bengal gram and black sesame had the highest score (8.3) than other chikkis. The selected combination was appealed to have good taste, low cost of production and better nutritional value (Abhirami and Karpagapandi, 2018). Pingale et al., 2019 evaluated sensory quality of amaranth grain and peanut blended chikki. The samples of chikki prepared from 40 percent amaranth grain and 60 percent peanut were found better with respect to organoleptic properties. The scores for amaranth and peanut blended chikki for color and appearance were 8.95 , while for texture it was 8.85 , for flavor 8.65 , for taste 8.65 . The score for overall acceptability was 8.7 .

Quinoa is considered as super food with the pack of essential proteins. Even though the application of quinoa is less mainly due to the saponin content, which gives bitterness in taste. The processing methods viz., germination and roasting were suitable for the reduction of bitterness and ease in consumption. Value added products developed from germination and roasting process scored like very much. Thus it was concluded that germination and roasting are the best household processing methods can be used as for the value addition in different traditional products without affecting the sensory parameters.

\section{References}

Abhirami, K. and Karpagapandi, L. 2018. Nutritional evaluation and storage stability of multigrain nutri-chikki. Int. J. Chem. Studies. 6(5): 3253-3259.

Abugoch, L., Castro, E., Tapia, C., Anon, M. C., Gajardo, P. and Villarroel, A. 2009. Stability of quinoa flour proteins (Chenopodium quinoaWilld.) during storage. Int. J. Food Sci. Tech. 44(10): 2013-2020.

Alba, V. C., Lazarte, C. E., Perez-rea, D., Sandberg, A. S., Carlsson, N. G., Almgren, A., Bergenståhl, B. and Granfeldt, Y. 2019. Effect of fermentation and dry roasting on the nutritional quality and sensory attributes of quinoa. Food Sci. Nutr. 7 (12): 3902-3911.

Anonymous. 2015, National agricultural statistics service. Agric. Static., USDA, Washington, pp: 441-446.

Benincasa, P., Falcinelli, B., Lutts, S., Stagnari, F., and Galieni, A. 2019. Sprouted Grains: A. Comprehensive Review.Nutr. 11 (2), 421-428.

Bianchi, F., Rossi, E., Gomes, R. and sivieri, K. 2015. Potentially synbiotic fermented beverage with aqueous extracts of quinoa (Chenopodium quinoa Wild) and soy. Food Sci. Technol. Int. 21 (6): 403-415.

Carciochi, R. A., Dimitrov, K. and Alessandro, L.G. 2016. Effect of malting conditions on phenolic content, Maillard reaction products formation, and antioxidant activity of quinoa seeds. J. Food Sci. Technol. 53 (11), 3978-3985.

Diaz, J. R. M., Kirjoranta, S., Tenitz, S., Penttilä, P. A., Serimaa, R., Lampi, A.M., and Jouppila, K. 2013. Use of amaranth, quinoa and kañiwa in extruded corn-based snacks. J. Cereal Sci. 58 (1): 59-67. 
Gindy, A, E. 2018. Preparation of some weaning food formulated from sweet potato, millet and quinoa, Curr. Sci. Int. 07 (04): 662-679.

Kaur, I. and Tanwar, B. 2016 Quinoa beverages: Formulation, processing and potential health benefits. Rom. J. Diabetes Nutri. and Metab. Dis. 23(2): 215-225.

Kavali, S., Shobha, D, Naik. R. S. and Brundha, A. R. 2019, Development of value-added products from quinoa using different cooking methods. Pharma Innovation, 8(7): 548-554.

Mir, N. A., Riar, C. S. and Singh, S. 2018. Nutritional constituents of pseudo cereals and their potential use in food systems: A review. Trends Food Sci. Technol. 75: 170-180

Miranda, M., Vega-gálvez, A., López, J., Parada, G., Sanders, M., Aranda, M., Uribe, E. and DI Scala, K. 2010. Impact of air-drying temperature on nutritional properties, total phenolic content and antioxidant capacity of quinoa seeds (Chenopodium quinoaWilld.). Ind. Crop. Prod. 32(3):
258-263.

Nadeem, M. K., Qaswar, M., Ahmed, N., Rabnawaz, M. and Rasool, S. J. 2017. Effect of seed soaking time on germination of maize (Zea mays L.). Biol Res, 2 (1): 46-50.

Pingale, A. A., Kotecha, P. M., Chavan, U. D. and Harsha, H. B. 2019. Nutritional evaluation and sensory quality of amaranth grain and peanut blended chikkiduring storage. BIOINFOLET-A Quarterly J. Life Sci. 16 (1and2): 2730.

Pinzino, C. 1999. Aging, free radicals and antioxidant in wheat seeds. J. Agric. Food Chem. 47:1333-1339.

Schoenlechner, R., Drausinger, J., Ottenschlaeger, V., Jurackova, K. and Berghofer, E. 2010. Functional properties of gluten-free pasta produced from amaranth, quinoa and buckwheat. Plant Foods Hum. Nutr. 65 (4): 339-349.

Sinkovic, L. 2016. Underutilized and pseudocereals in the mediterranean diet. Austin Food Sci. 1(5): 1-2.

\section{How to cite this article:}

Pritham, S. M., M. L. Revanna, Usha Ravindra, B. Kalpana, Niranjana Murthy and Madhusudan. 2021. Quinoa (Chenopodium quinoa) Grains Processing and its Value Added Products. Int.J.Curr.Microbiol.App.Sci. 10(04): 681-691. doi: https://doi.org/10.20546/ijcmas.2021.1004.068 